\title{
Dependence of pigment content in meadow clover leaves on soil phosphorus level
}

\author{
I. V. Lyskova ${ }^{1}$ and E. M. Lisitsyn ${ }^{1,2^{*}}$ \\ ${ }^{1}$ Federal Agricultural Research Center of the North-East, Kirov, 610007, Russian Federation \\ ${ }^{2}$ Vyatka State Agricultural Academy, Kirov, 610017, Russian Federation
}

\begin{abstract}
In 2018-2019, the effect of different levels of soil phosphorus on the pigment complex of the clover (Trifolium pratense L.) leaves was assessed. Total chlorophyll content was 15.34-19.05 and 11.47-14.10 mg g1 dry matter, of which Chl a accounted for 9.64-11.36 and 6.67-7.98 mg g-1 (2018 and 2019 respectively). Carotenoids content varied within 2.69-3.12 and $1.52-1.88 \mathrm{mg}$ g-1 in 2018 and 2019 respectively. Weight ratio of total chlorophyll/carotinoids (5.7-6.7 in 2018 and 6.8-9.6 in 2019) gives the grounds to consider that there was not disorders in structure of the pigment complexes of leaves in both year. There were statistically significant linkage of level of soil phosphorus with $\mathrm{Chl}$ a $(\mathrm{r}=0.536-0.743)$ and $\mathrm{Chl} \mathrm{b}(\mathrm{r}=$ $0.725-0.748$ ) in cooler conditions of 2019. In wormer 2018, these links were insignificant $(\mathrm{Chl} \mathrm{a}=-0.146$ to -0.286 and $\mathrm{Chl} \mathrm{b}=-0.257$ to -0.275$)$. Correlation between phosphorus content in soil and carotenoids content in leaves was insignificant in all cases. Chl pigments showed a polynomial second order relationship with level of soil phosphorus. In 2019, these relations was statistically significant at $\mathrm{p} \leq 0.05(\mathrm{R} 2=0.68-0.76)$ for both chlorophylls. Under conditions of 2018 these relations was insignificant (R2 $=0.10-0.43$ ).
\end{abstract}

\section{Introduction}

Growing concern about the negative side effects of modern agriculture has stimulated the need to find new agronomic solutions to improve the ecological profile of agricultural systems $[1,2]$. In this regard, the role of cover crops, which can increase yields, as well as reduce environmental impact in agricultural systems, is increased [1,3]. In addition, they are able to modify significantly soil conditions: reduce the degree of compaction and erosion [1], increase porosity [4], improve the ability to retain and remobilize nutrients [5], enrich the soil with organic substance, especially in the case of legume species [6], and increase the availability of phosphorus to plants [7]. However, these useful functions require knowledge of the suitability of the species for different agro-ecological conditions, with particular attention to changes in soil properties [8]. Therefore, understanding the factors that regulate the productivity of cover crops under the stress of the growth medium is a necessary task of modern agriculture.

The basis of plant productivity is the activity of the photosynthetic apparatus of leaves. Chlorophylls and carotenoids are its most important components. Of the fodder crops,

* Corresponding author: edaphic@mail.ru 
legumes are the most rich in chlorophyll and carotenoids. Among them, meadow clover is designated which leaves significantly exceed in the content of chlorophyll such legumes as lupine, soybean, beans [9].

The amount of pigments varies when adapted to the environment and under the influence of various stressors, i.e. reflects the plant's response to growing conditions [10]. Early structural changes occur in leaf chloroplasts experiencing various abiotic stresses [11]. Under the conditions of sodpodzolic soils, the main stressful edaphic factor is the high content of mobile aluminum ions. For example, under the conditions of the Falenki breeding station, the aluminum content in the upper horizons of natural soils reaches values of 250-300 mg kg-1 of soil [12]. Under such conditions, the availability of macronutrients such as phosphorus to plants is of particular importance. We have previously found that the annual application of superphosphate at a dose of $50 \mathrm{~kg}$ ha-1 provided a content of mobile phosphorus at the lower optimal boundary (not less than $100 \mathrm{mg} \mathrm{kg}-1$ of soil). Superphosphate application in doses of 100, 150, $200 \mathrm{~kg}$ ha-1 (annually) provided the content of mobile phosphorus on the limed soil background from 222 to $376 \mathrm{mg} \mathrm{kg}-1$, on the acidic background - from 191 to $285 \mathrm{mg} \mathrm{kg}-1$ [12].

The aim of the study is to assess the effect of phosphorus content in the soil on the qualitative and quantitative composition of the pigment complex of the meadow clover (Trifolium pratense L.) leaves under different hydrothermal conditions.

\section{Materials and methods}

The study was carried out in conditions of long-term stationary experiment of Falenki breeding station (eastern agro-climatic area of the central zone of Kirov region, Russian Federation). The soil is classified as middle loam sod-podzolic formed on cover loams. The total area of plot is $40.25 \mathrm{~m} 2$, the replication is quadruple. In 2008-2014, fertilizers were applicated according to the following scheme: 1. Control (without fertilizers); 2. N90; 3 . N90P50K90; 4. N90P100K90; 5. N90P150K90; 6. N90P200K90. In 2009, the background was re-limed for 1 hydrolytic acidity. In 2015-2019, the following fertilizer application scheme was used: 1 . Control (without fertilizers); 2. N90; 3 - 6. N90P50K90. Variants 3 to 6 differed in the content of mobile phosphorus in the soil. These schemes were used both in natural soil background ( $\mathrm{pH} 3.68$ ) and limed soil background ( $\mathrm{pH}$ 5.60).

In order to evaluate the pigment complex, leaves samples of meadow clover cv. Dymkovsky were taken from twenty individual plants in the flowering phase (30 fully developed 2-3 upper leaves) on both soil backgrounds in 6-fold replication. Under laboratory conditions, "UVmini-1240" spectrophotometer (SHIMADZU Corporation, Japan) was used to determine the content of green and yellow pigments recovered by $100 \%$ acetone. Further, chlorophylls a and $\mathrm{b}(\mathrm{Chl} \mathrm{a}, \mathrm{Chl} \mathrm{b})$ and carotenoids (Car) per unit dry weight were calculated by the formulae of [13].

It is known that weather conditions of the growing period have a direct impact on the physiological processes of plant growth and development. Since samples were taken in the second half of June, the accumulation of pigments by this date could have been influenced by the weather conditions of last 15-day period of June. Second half of June 2018 was rather warm and low in precipitations (figure 1).

The summer period in 2019 was characterized by wet weather, with a lack of heat: in June the sum of precipitation consists $164 \%$ of average long-time data at the air temperature lower by $1{ }^{\circ} \mathrm{C}$ of the climatic rate. A small shortage of heat and excess precipitation had a favourable effect on the formation of the leaf apparatus of plants.

Statistical data processing was carried out using descriptive statistics, correlation, regression and variance analysis methods using the AGROS 2.07 selection-oriented 
statistical software package and the Microsoft Office Excel 2016 table editor. The tables show the mean values and their standard errors.

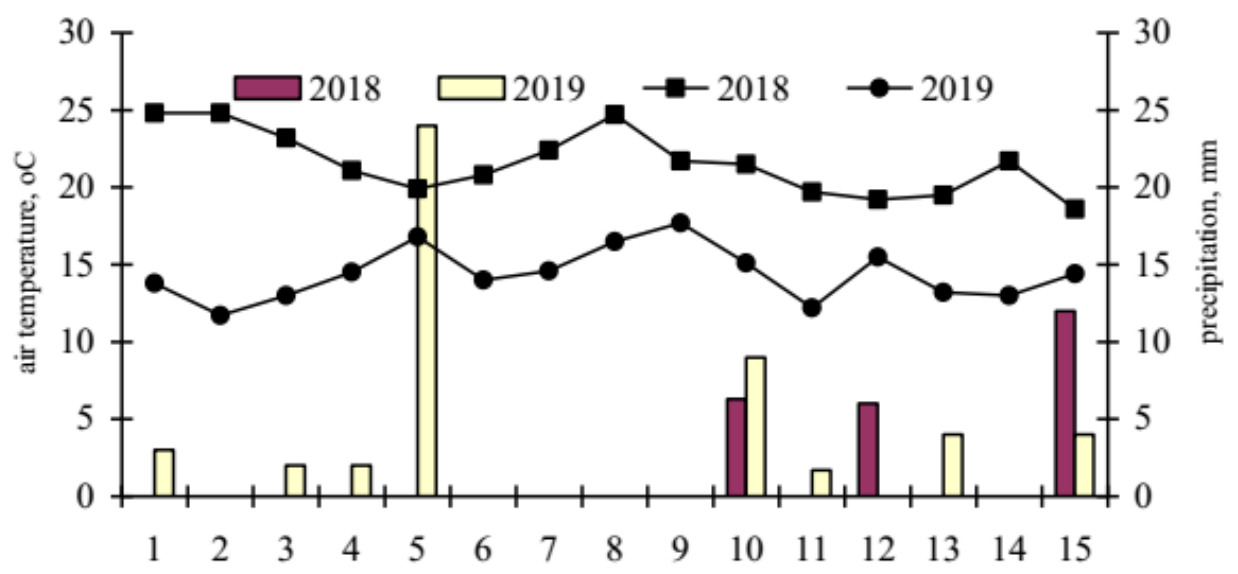

Fig. 1. Meteorological features of 15 -day period before sample collection, Falenki breeding station, Kirov region of Russian Federation. Air temperature - lines; precipitations - dendrogram

\section{Results}

Many years of application of phosphorus fertilizers according to the same scheme allowed to create different levels of phosphorus content in soil (table 1,2) by the beginning of the study. According to the obtained data, the concentration of green pigments (Chl a and b) in clover leaves in 2018 was in the range of 15.34-19.05 mg g-1 of dry matter (table 1), of which 9.64-11.36 mg g-1 was $\mathrm{Chl}$ a. The mass ratio of $\mathrm{Chl} \mathrm{a/b}$ was within 1.54-1.75, with the part of Chl a in LHC (light-harvesting complex) being 69-78\% of its total chloroplasts content.

Table 1. Parameters of development of clover leaves' pigment complex (mg g-1 of dry matter), 2018.

\begin{tabular}{|c|c|c|c|c|c|c|}
\hline Variant & & $\begin{array}{l}\text { Content of P } \\
\text { in soil, } \\
\mathrm{mg} \mathrm{kg}^{-1}\end{array}$ & $\begin{array}{c}\text { Content of } \mathrm{N} \\
\text { in leaf tissues, } \\
\%\end{array}$ & Chl a & Chl b & Car \\
\hline \multicolumn{7}{|c|}{ No lime input } \\
\hline P0 & & $84.0 \pm 13.0$ & $2.85 \pm 0.28$ & $11.90 \pm 0.53$ & $7.15 \pm 0.35$ & $3.12 \pm 0.09$ \\
\hline $\mathrm{P} 0+\mathrm{N} 90$ & & $77.0 \pm 12.0$ & $2.64 \pm 0.04$ & $10.60 \pm 0.40$ & $6.36 \pm 0.23$ & $2.78 \pm 0.12$ \\
\hline $\begin{array}{l}\text { P50 } \\
\text { N90K90 }\end{array}$ & + & $120.5 \pm 11.5$ & $2.83 \pm 0.28$ & $11.07 \pm 0.16$ & $6.38 \pm 0.09$ & $2.98 \pm 0.09$ \\
\hline $\begin{array}{l}\text { P100 } \\
\text { N90K90 }\end{array}$ & + & $170.0 \pm 15.0$ & $2.95 \pm 0.07$ & $10.44 \pm 0.29$ & $5.98 \pm 0.16$ & $2.86 \pm 0.07$ \\
\hline $\begin{array}{l}\text { P150 } \\
\text { N90K90 }\end{array}$ & + & $232.0 \pm 16.0$ & $2.69 \pm 0.11$ & $10.97 \pm 0.87$ & $7.14 \pm 0.67$ & $2.74 \pm 0.22$ \\
\hline $\begin{array}{l}\text { P200 } \\
\text { N90K90 }\end{array}$ & + & $195.0 \pm 7.0$ & $2.80 \pm 0.24$ & $10.80 \pm 0.25$ & $6.31 \pm 0.20$ & $2.91 \pm 0.10$ \\
\hline \multicolumn{7}{|c|}{ Lime input according to 1 unit of hydrolytic acidity } \\
\hline P0 & & $66.0 \pm 10.0$ & $3.08 \pm 0.01$ & $11.36 \pm 0.79$ & $7.31 \pm 0.52$ & $2.80 \pm 0.16$ \\
\hline $\mathrm{P} 0+\mathrm{N} 90$ & & $89.0 \pm 12.0$ & $3.12 \pm 0.16$ & $9.64 \pm 0.36$ & $5.70 \pm 0.35$ & $2.69 \pm 0.05$ \\
\hline $\begin{array}{l}\text { P50 } \\
\text { N90K90 }\end{array}$ & + & $142.0 \pm 10.1$ & $3.25 \pm 0.34$ & $11.34 \pm 0.47$ & $6.97 \pm 0.35$ & $2.93 \pm 0.13$ \\
\hline
\end{tabular}




\begin{tabular}{|c|c|c|c|c|c|c|}
\hline $\begin{array}{l}\text { P100 } \\
\text { N90K90 }\end{array}$ & + & $207.5 \pm 25.5$ & $3.39 \pm 0.13$ & $10.57 \pm 0.38$ & $6.58 \pm 0.38$ & $2.82 \pm 0.05$ \\
\hline $\begin{array}{l}\text { P150 } \\
\text { N90K90 }\end{array}$ & + & $290.5 \pm 11.5$ & $3.30 \pm 0.24$ & $10.21 \pm 0.27$ & $6.39 \pm 0.18$ & $2.62 \pm 0.12$ \\
\hline $\begin{array}{l}\text { P200 } \\
\text { N90K90 }\end{array}$ & + & $213.5 \pm 43.5$ & $2.97 \pm 0.10$ & $10.22 \pm 0.45$ & $6.43 \pm 0.31$ & $2.67 \pm 0.14$ \\
\hline
\end{tabular}

Carotenoids content was $2.69-3.12 \mathrm{mg}$ g-1 and were significantly correlated with total chlorophyll $(\mathrm{r}=0.82)$. The $\mathrm{Chl} / \mathrm{Car}$ mass ratio was 5.7-6.7.

Under acidic soil conditions (no lime input, $\mathrm{pH} 3.68$ ), the nitrogen application (variant $\mathrm{P} 0+\mathrm{N} 90)$ resulted in a reduction of all three pigments by $11 \%$ in compare with the control variant (P0). Application of complete mineral fertilizer (NPK, remaining variants of experiment) reduced content of Chl a by $8.9 \%$, Chl b - by $11.7 \%$, carotenoids - by $6.7 \%$. Liming raised the $\mathrm{pH}$ of the soil solution to 5.60. These conditions increased the depressive effect of nitrogen application (variant $\mathrm{P} 0+\mathrm{N} 90$ ): reduction in Chl a content reached $15.2 \%$, $\mathrm{Chl} \mathrm{b}-22.1 \%$; However, application of addition phosphorus and potassium (complete mineral fertilizer) made the differences from the control (P0) statistically insignificant. In both variants of soil background, there is no statistically significant relationship between nitrogen and chlorophyll content in leaves, as well as between nitrogen content in leaves and phosphorus content in soil.

Coefficients of pair correlation between level of phosphorus in soil and content of pigments in leaves were as follow: in natural acidic soil conditions with $\mathrm{Chl} a=-0.146$; with $\mathrm{Chl} b=-0.257$; with $\mathrm{Car}=-0.298$; in limed soil background $\mathrm{r}=-0.286 ;-0.275 ;-0.305$ correspondingly at critical level of $0.497(\mathrm{p} \leq 0.05)$.

Analysis of the pigment complex of meadows clover's leaves in 2019 (table 2) showed a significant decrease in the content of all pigments relative to 2018.

Table 2. Parameters of development of clover leaves' pigment complex (mg g-1 of dry matter), 2019.

\begin{tabular}{|c|c|c|c|c|c|c|}
\hline Variant & & $\begin{array}{l}\text { Content of P } \\
\text { in soil, } \\
\text { mg kg-1 }\end{array}$ & $\begin{array}{c}\text { Content of } \mathrm{N} \\
\text { in leaf tissues, } \\
\%\end{array}$ & Chl a & Chl b & Car \\
\hline \multicolumn{7}{|c|}{ No lime input } \\
\hline P0 & & $84.0 \pm 13.0$ & $1.88 \pm 0.07$ & $6.67 \pm 0.35$ & $4.98 \pm 0.21$ & $1.59 \pm 0.13$ \\
\hline $\mathrm{P} 0+\mathrm{N} 90$ & & $77.0 \pm 12.0$ & $2.00 \pm 0.13$ & $6.98 \pm 0.37$ & $5.15 \pm 0.39$ & $1.62 \pm 0.08$ \\
\hline $\begin{array}{l}\text { P50 } \\
\text { N90K90 }\end{array}$ & + & $120.5 \pm 11.5$ & $2.46 \pm 0.14$ & $7.86 \pm 0.22$ & $5.53 \pm 0.35$ & $1.88 \pm 0.12$ \\
\hline $\begin{array}{l}\text { P100 } \\
\text { N90K90 }\end{array}$ & + & $170.0 \pm 15.0$ & $2.37 \pm 0.16$ & $7.92 \pm 0.28$ & $6.12 \pm 0.38$ & $1.77 \pm 0.10$ \\
\hline $\begin{array}{l}\text { P150 } \\
\text { N90K90 }\end{array}$ & + & $232.0 \pm 16.0$ & $2.34 \pm 0.26$ & $7.98 \pm 0.32$ & $5.94 \pm 0.18$ & $1.82 \pm 0.12$ \\
\hline $\begin{array}{l}\text { P200 } \\
\text { N90K90 }\end{array}$ & + & $195.0 \pm 7.0$ & $2.28 \pm 0.25$ & $7.75 \pm 0.22$ & $6.35 \pm 0.18$ & $1.64 \pm 0.09$ \\
\hline \multicolumn{7}{|c|}{ Lime input according to 1 unit of hydrolytic acidity } \\
\hline P0 & & $66.0 \pm 10.0$ & $1.98 \pm 0.09$ & $6.70 \pm 0.26$ & $4.77 \pm 0.07$ & $1.67 \pm 0.12$ \\
\hline $\mathrm{P} 0+\mathrm{N} 90$ & & $89.0 \pm 12.0$ & $2.08 \pm 0.21$ & $7.15 \pm 0.18$ & $4.90 \pm 0.21$ & $1.76 \pm 0.03$ \\
\hline $\begin{array}{l}\text { P50 } \\
\text { N90K90 }\end{array}$ & + & $142.0 \pm 10.1$ & $2.44 \pm 0.07$ & $7.76 \pm 0.17$ & $5.71 \pm 0.11$ & $1.80 \pm 0.08$ \\
\hline $\begin{array}{l}\text { P100 } \\
\text { N90K90 }\end{array}$ & + & $207.5 \pm 25.5$ & $2.10 \pm 0.18$ & $7.47 \pm 0.36$ & $6.31 \pm 0.31$ & $1.52 \pm 0.11$ \\
\hline $\begin{array}{l}\text { P150 } \\
\text { N90K90 }\end{array}$ & + & $290.5 \pm 11.5$ & $2.31 \pm 0.23$ & $7.65 \pm 0.23$ & $5.98 \pm 0.37$ & $1.68 \pm 0.06$ \\
\hline
\end{tabular}




\begin{tabular}{|c|c|c|c|c|c|c|}
\hline $\begin{array}{l}\text { P200 } \\
\text { N90K90 }\end{array}$ & + & $213.5 \pm 43.5$ & $2.53 \pm 0.04$ & $7.77 \pm 0.16$ & $5.70 \pm 0.14$ & $1.83 \pm 0.03$ \\
\hline
\end{tabular}

The total chlorophyll content was in the range of $11.47-14.10 \mathrm{mg}$ g-1 dry matter. The average amount of green pigments on the natural acidic soil background is slightly higher than on the background with lime application (13.21 and $12.98 \mathrm{mg}$ g-1, respectively). The Chl a content was also lower (6.67-7.98 $\mathrm{mg}$ g-1), with LHC rising to $89 \ldots 96 \%$. The mass ratio $\mathrm{Chl} \mathrm{a} / \mathrm{b}$ was within $1.18 \ldots 1.47$.

The carotenoid content decreased in proportion to the decrease in chlorophyll content and ranged from 1.52 to $1.88 \mathrm{mg}$ g-1 dry matter. The correlation coefficient between carotenoids and Chl a was high positive on both soil backgrounds and was 0.538-0.721, whereas with $\mathrm{Chl} b$ this relationship was statistically significant at $\mathrm{p} \leq 0.05$ but negative (0.321 ) only when the soil was limed.

The solely action of nitrogen (without phosphorus and lime) did not affect the content of pigments, and the action of the complete mineral fertilizer without calcium increased the content of Chl a by $17.8 \%$, carotenoids - by $18.2 \%$. Under lime application, NPK fertilizing increased the content of these pigments by 14.1 and $25.4 \%$, respectively. No significant changes at $\mathrm{p} \leq 0.05$ in $\mathrm{Chl} b$ content are noted in all cases.

In 2019, a statistically significant correlation between Chl a and nitrogen in leaves ( $\mathrm{r}=$ 0.92 and 0.52 for natural acidic and limed soil background, respectively) appeared. Under natural acidic soil conditions, the nitrogen content of the leaves was also significantly related to the $\mathrm{Chl} \mathrm{b}$ content $(\mathrm{r}=0.78)$ at $\mathrm{p} \leq 0.05$.

Coefficients of pair correlation between level of phosphorus in soil and content of pigments in leaves were as follow: in natural acidic soil conditions with $\mathrm{Chl} \mathrm{a}=0.743$; with $\mathrm{Chl} b=0.725$; with $\mathrm{Car}=0.353$; in limed soil background $\mathrm{r}=0.536 ; 0.748 ;-0.145$ correspondingly at critical level of $0.497(\mathrm{p} \leq 0.05)$.

An analysis of the relationship of photosynthetic pigment content in clover leaves to phosphorus content in soil is shown in Figures 2, 3.

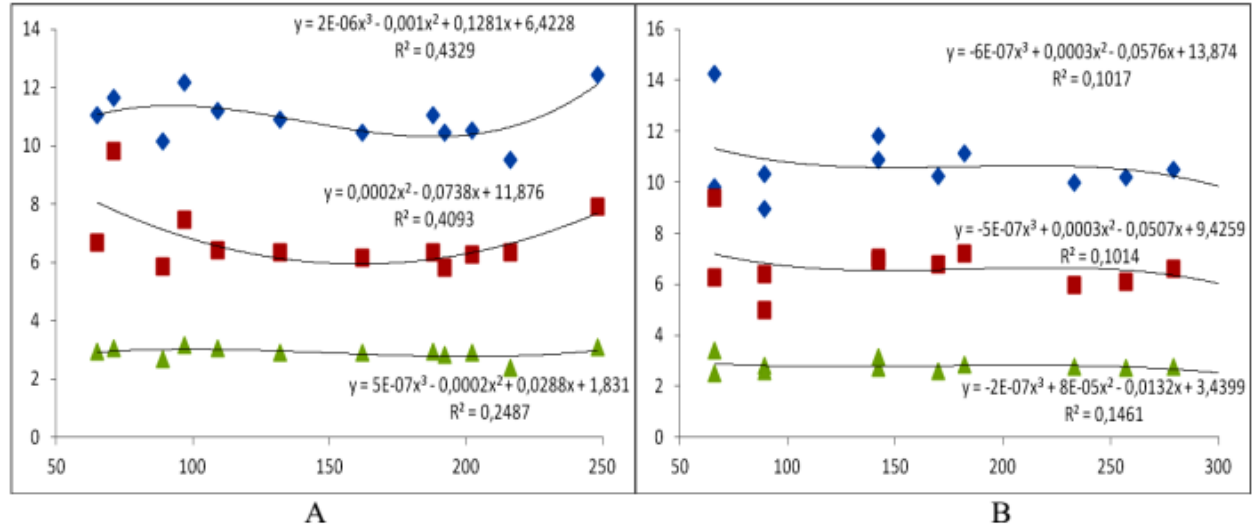

Fig. 2. Interrelation between phosphorus content in soil (horizontal axis, $\mathrm{mg} \mathrm{kg-1)}$ with pigment content in leaves (vertical axis, mg g-1 dry matter), 2018.

Upper curve - chlorophyll $a$, middle curve - chlorophyll $b$, lower curve - carotenoids. A - natural acid soil, pH 3.68; B - limed soil, pH 5.60. 


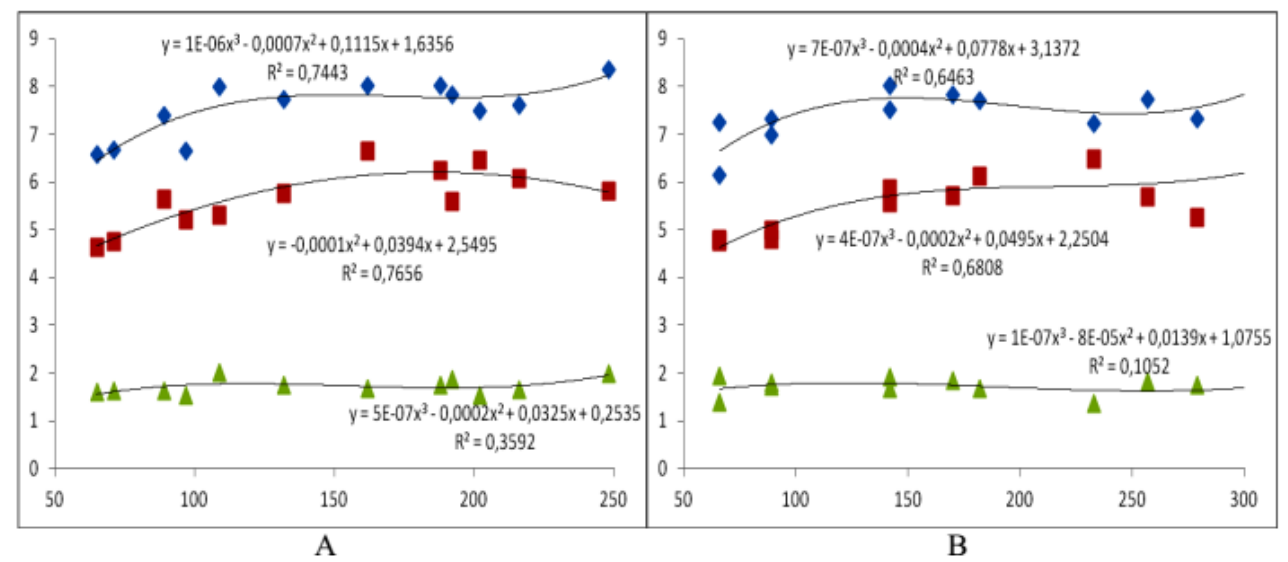

Figure 3. Interrelation between phosphorus content in soil (horizontal axis, mg kg-1) with pigment content in leaves (vertical axis, mg g-1 dry matter), 2019.

Upper curve - chlorophyll a, middle curve - chlorophyll b, lower curve - carotenoids. A - natural acid soil, pH 3.68; B - limed soil, pH 5.60.

As shown in Figures 2 and 3, a polynomial second order relationship is the best equation describing the relationship of the parameters studied. In the cooler weather conditions of 2019 , this relation becomes statistically significant at $\mathrm{p} \leq 0.05(\mathrm{R} 2=0.68$ 0.76 ) for both chlorophylls. However, our study failed to identify statistically significant relationships between the phosphorus content in soil and carotenoids in clover leaves (R2 = 0.10-0.36).

The effect of phosphorus on photosynthetic pigment content in clover leaves was more evident in low soil pH conditions, especially in 2019.

Data of two-way ANOVA involving "liming" and "soil phosphorus content" factors showed no statistically significant at $\mathrm{p} \leq 0.05$ effect of calcium application and increased content of phosphorus (variants 3-6) on Chl a and Chl b levels under 2018 year conditions. On the other hand, two-way ANOVA taking into account the factors "liming" and "application of various macronutrients" (variant 1 - without fertilization; variant 2 nitrogen application; averaged variants 3-6 - phosphorus, nitrogen and potassium application) showed that macronutrients application explains up to $23.3 \%$ variability of $\mathrm{Chl}$ a content and $26.9 \%$ variability of $\mathrm{Chl} b$ content.

Unlike green pigments, the content of carotenoids was significantly dependent on the application of calcium (liming): its effect explains $12.5 \%$ of the variability of this pigment. The remaining factors of mineral nutrition - nitrogen or complete fertilization - did not affect the accumulation of this additional photosynthetic pigment.

In 2019, there was a statistically significant at $\mathrm{p} \leq 0.05$ correlation dependence of $\mathrm{Chl}$ a content on such factors as liming and application of mineral nutrition elements: the first factor explains $21.0 \%$ of pigment content variability, the second - $33.3 \%$. No interaction of factors was observed. The variability of $\mathrm{Chl} \mathrm{b}$ content was influenced by the effect of mineral fertilizers (the ratio of influence of this factor was $24.9 \%$ ) only. The carotenoid content did not differ statistically for samples taken from all the variants studied.

In general, for two years of study, the calculation of the degree of influence of the studied factors was carried out in two stages. In the first stage, only variants 3 to 6 were studied, i.e. factors - year, liming, level of phosphorus content - were taken into account. This formation of the analysis matrix showed a significant at $\mathrm{p} \leq 0.05$ effect of factor 'year' only. The effect of this factor on Chl a variability was $74.2 \%$, Chl b $12.3 \%$ and Car $79.6 \%$. 
Since the effect of the phosphorus level was statistically insignificant at $p \leq 0.05$, for the second stage of the calculations, the data for variants 3 to 6 were averaged into one "complete fertilizer" factor. Three factors were taken into account: year, liming and application of mineral nutrition (variant 1 - without fertilizers, variant 2 - nitrogen application, averaged variants 3 - 6 - complete fertilizer application). This approach found that the $84.3 \%$ variation in carotenoid content was due to the influence of the conditions of the year; Variability of $\mathrm{Chl}$ a content is explained by $71.8 \%$ by influence of year conditions and by $2.1 \%$ - by action of mineral nutrients. Chl b content was affected in almost equal proportion by the conditions of the year $(8.6 \%)$ and macronutrients $(6.5 \%)$. For all three pigments, there was no statistically significant effect of liming.

\section{Discussion}

It is widely considered that plants for high efficiency should adjust its pigmentary complex to adapt to a given soil and weather conditions.

In our study significant differences in pigment content in clover leaves in 2018 and 2019 were likely determined by weather conditions. It is known that the optimum temperature of general plant chlorophyll synthesis is $30^{\circ} \mathrm{C}$ [14]. Low positive temperatures (lower than $15 \mathrm{oC}$ ) can cause degradation of the thylakoid structure and distortion in lightdependent photosynthetic reactions [15], especially with long-acting stress stimulus [16]. Some of the absorbed light quanta would be counted as excess energy that often initiates singlet oxygen overproduction, followed by photooxidative damage and cell death. Decreasing chlorophyll content in plant leaves under low temperature is often considered a typical symptom of oxidative stress $[17,18]$.

Singh and Reddy [19] suggested the decrease in Chl concentration as a mechanism to avoid excess light harvesting to protect PSII from photodamage. However, it is possible to estimate the influence of abiotic stress factors on plants more correctly by weight ratios of chlorophyll $\mathrm{a} / \mathrm{b}$ and total chlorophyll to carotenoids. The ratio between chlorophyll and carotenoids has been much less widely used diagnostically, although relationship is a very good indicator of disturbances caused in the plants by environmental factors [20]. Under the conditions of 2018, the mass ratio $\mathrm{Chl} / \mathrm{Car}$ was 5.7-6.7, in 2019 slightly higher - 6.8-9.6, which, according to [13], may indicate the absence of serious structural damage to the photosynthetic apparatus. Close values of $\mathrm{Chl} \mathrm{a/b}$ ratios (1.54-1.75 and 1.18-1.47 in 2018 and 2019, respectively) also indicate close relative levels of pigment content. In analyzing the response of the soybean leaf pigment complex to phosphorus deficiency, [21] also noted fairly stable the $\mathrm{Chl} \mathrm{a} / \mathrm{b}$ and the $\mathrm{Chl} / \mathrm{Car}$ ratios across leaf $\mathrm{P}$ concentration. Chl a/b ratio might have been maintained without a substantial impact of $\mathrm{P}$ deficiency. These data suggest that no significant structural and functional damage to clover leaf pigment complex was observed in both years. The differences in pigment content noted in our work are most likely the result of a decrease in the rate of chlorophyll synthesis under conditions of prolonged exposure to low (below $15^{\circ} \mathrm{C}$ ) positive air temperatures (see Figure 1). The same finding is supported by data from a three-way ANOVA showing that conditions of year (mostly temperature and precipitation) can explain up to $72-74 \%$ variability of $\mathrm{Chl}$ a content and up to $80-84 \%$ variability of carotenoids content.

In addition to the effect on pigment synthesis, the growing temperature conditions significantly changed the degree of dependence of the leaf pigment content on the phosphorus concentration in the soil. Chlorophyll synthesis requires many macronutrients especially nitrogen and phosphorous from soils [22]. Deficiency in macronutrients (N, P, K, or $\mathrm{Ca}$ ) disrupts the functioning of the photosynthetic apparatus [23]. Major deficits in 
phosphorus cause modifications in thylakoid structure of chloroplasts and in lightharvesting complexes thus reducing activity of PSII [24].

It is believed that a significant part of the nitrogen in the leaves is contained in chlorophyll molecules, since a number of studies show a direct relationship between these two parameters because the majority of leaf $\mathrm{N}$ is contained in chlorophyll molecules [25, 26]. In our studies, statistically significant at $\mathrm{p} \leq 0.05$ links between chlorophyll and nitrogen in clover leaves were found only in cooler 2019 conditions, with $\mathrm{Chl}$ a in leaves being high and expressed on both soil backgrounds ( $\mathrm{pH} 3.68$ and 5.60), whereas with $\mathrm{Chl} \mathrm{b}$ the link was substantially lower and manifested only in natural low soil $\mathrm{pH}$ conditions. It should be noted that under natural acidic soil conditions a statistically significant link of nitrogen content in clover leaves and phosphorus content in soil was observed in $2019(\mathrm{r}=$ $0.49)$.

Although most researchers usually determine the positive effect of nitrogen fertilizers on chlorophyll synthesis in leaves [27, 28], there are also studies that indicate that nitrogen can lead to a decrease in pigment concentration [29], or do not have a statistically significant effect on the studied parameters [30] depending on the year of studies, dose and form of nitrogen fertilizer used. Our data show that the application of nitrogen at $90 \mathrm{~kg}$ ha-1 under cool growing season conditions had weak effect on the synthesis of photosynthetic pigments.

In our study with clover $\mathrm{Chl}$ pigments (i.e., $\mathrm{Chl} \mathrm{a}, \mathrm{Chl}$ b) showed a polynomial second order relationship with amount of soil phosphorus. A similar nature of dependence between the parameters studied was previously noted for soybean plants [21], where content of leaf pigments correlate in such a way with leaf $\mathrm{P}$ concentration. A large range of plant species shows a direct link between phosphorus content in soil and plant tissues [31, 32]. The nonlinear nature of the observed relationship may indicate that even under conditions of prolonged exposure to suboptimal temperatures (below $15^{\circ} \mathrm{C}$ ), competition for phosphorus available to plants occurs between different physiological processes in the plant. As a result, the processes of synthesis and accumulation of chlorophylls consume a different proportion of the received phosphorus.

Our study failed to show significant relationships between soil phosphorus content and clover leaf carotenoid content in neither 2018 nor 2019 at both soil pH values (3.68 and 5.60). This data is consistent with observations [21] that Car concentration and $\mathrm{Chl} \mathrm{a/b}$ ratio did not show a significant relationship with leaf $\mathrm{P}$ concentration. According to [33], this indicates importance of carotenoids in the photoprotection of PSII. Similar conclusions were reached in study [19] where authors suggested the decrease in Chl concentration as a mechanism to avoid excess light harvesting to protect PSII from photodamage under $\mathrm{P}$ deficiency.

\section{Conclusions}

Thus, the content of pigments in the leaves of the meadow clover was most dependent on the conditions of the growing year. Based on the weight ratio of chlorophylls $\mathrm{a} / \mathrm{b}$ (1.541.75 in 2018 and 1.18-1.47 in 2019) and mass ratio of the sum of chlorophylls to carotenoids (5.7-6.7 in 2018 and 6.8-9.6 in 2019) one could proposed that even unfavorable weather did not lead to disorders of the structure of the photosynthetic apparatus of the leaves of the meadow clover.

The effect of phosphorus on chlorophyll content in clover leaves was more evident in cooler conditions of 2019. There were statistically significant linkage between level of soil phosphorus with $\mathrm{Chl} \mathrm{a}(\mathrm{r}=0.536-0.743)$ and $\mathrm{Chl} \mathrm{b}(\mathrm{r}=0.725-0.748)$ whereas in wormer 2018 these links were insignificant ( $\mathrm{Chl} \mathrm{a}=-0.146$ to -0.286 and $\mathrm{Chl} \mathrm{b}=-0.257$ to -0.275 ). 
Correlation between phosphorus content in soil and Car content in leaves was insignificant in all cases.

Chl pigments showed a polynomial second order relationship with level of soil phosphorus. In the cooler weather conditions of 2019, these relations was statistically significant at $\mathrm{p} \leq 0.05(\mathrm{R} 2=0.68-0.76)$ for both chlorophylls. Under higher air temperature conditions of 2018 these relations was insignificant $(\mathrm{R} 2=0.10-0.43)$.

\section{References}

1. Scopel E, Triomphe B, Affholder F, Macena Da Silva FA, Corbeels M, Valadares Xavier J.H, Lahmar R, Recous S, Bernoux M and Blanchart E et al. 2013 A review Agron. Sustain. Dev. 33 113-30

2. Mauro R P, Sortino O, Dipasquale M and Mauromicale G 2014 J. Agric. Sci. 152 917-31

3. Djigal D, Saj S, Rabary B, Blanchart E and Villenave C 2012 Soil Till. Res. 118 1121

4. Carof M, De Tourdonnet S, Coquet Y, Hallaire V and Roger-Estrade J 2007 Soil Use Manage. 23 230-7

5. Doltra J and Olesen J E 2013 Eur. J. Agron. 44 98-108

6. Stagno F, Abbate C, Intrigliolo F, Abbate V and Gennari M 2008 Ital. J. Agron. 3 183-90

7. Kamh M, Horst W J, Amer F, Mostafa H and Maier P 1999 Plant Soil 211 19-27

8. Mauro R P, Anastasi U, Lombardo S, Pandino G, Pesce R, Restuccia A and Mauromicale G 2015 Italian Journal of Agronomy 10(641) 101-4

9. Kurenkova S V 1976 Physiology and biochemistry of cultivated plants in North (Leningrad: Nauka Publ.) pp. 28-35. (in Russian)

10. Lisitsyn E M, Kedrova L I, Utkina E I and Zlobina N A 2010 Agricultural Science Euro-North-East 1(16) 20-4. (in Russian)

11. Zhang F, Lu K, Gu Y, Zhang L, Li W and Li Z 2020 Front. Plant Sci. 101767

12. Lyskova I V, Rylova O N, Veselkova N A and Lyskova T V 2015 Agricultural Science Euro-North-East. 2(45) 27-32 (in Russian)

13. Lichtenthaler H K and Buschmann C 2001 Current protocols in food analytical chemistry F.4.3.1-F.4.3.8

14. Nagata N, Tanaka R, Satoh S and Tanaka A 2005 Prochlorococcus species Plant Cell 17 233-40

15. Suzuki K, Ohmori Y and Ratel E 2011 Plant Cell Physiology 52(9) 1697-707

16. Murata N, Takahashi S, Nishiyama Y and Allakhverdiev S I 2007 BBABioenergetics 1767(6):414-21

17. Yadegari L Z, Heidari R and Carapetian J 2007 Journal of Biological Sciences 7 1436-41

18. Wojciechowska R, Kalisz A, Sekara A, Nosek M, Cebula S, Miszalski Z, Kunicki E and Grabovska A 2016 Not Bot Horti Agrobo 44(1) 17-24

19. Singh S K and Reddy V R 2016 Physiol. Plantarum 157 234-54

20. Hendry G A F and Price A H 1993 Comparative Plant Ecology (ed. G A F Hendry and J P Grime Chapman \& Hall, London) pp. 148-152 
21. Singh S K, Reddy V R, Fleisher D H and Timlin D J 2017 Photosynthetica 55(3) 421-33

22. Li Y, He N, Hou J, Xu L, Liu C, Zhang J, Wang Q, Zhang X and Wu X 2018 Front. Ecol. Evol. 664

23. Smethurst C F, Garnett T and Shabala S 2005 Plant Soil 270(1) 31-45

24. Foyer C and Spencer C 1986 leaves Planta 167(3) 369-75

25. Evans J R 1983 Plant Physiology 72 297-302

26. Bojovic B and Markovic A 2009 Kragujevac J. Sci. 31 69-74

27. Lamptey S, Li L, Xie J, Zhang R, Yeboah S and Antille D L 2017 Crop Sci. 57 $2739-52$

28. Wamalwa D S, Sikuku P A, Netondo G W and Khasabulli B D 2019 International Journal of Plant \& Soil Science 27(4) 1-9

29. Kononov A S and Shkotova O N 2012 Bryanskogo Gosudarstvennogo Universiteta 4(1) 103-6 (in Russian)

30. Skudra I and Ruza A 2017 Rural Sustainability Research 37(332) 29-37

31. Ordoñez J C, Van Bodegom P M, Witte J P M, Wright I J, Reich P B and Aerts R 2009 Global Ecol Biogeogr 18 137-49

32. Tang Z, Xu W, Zhou G, Bai Y, Li J, Tang X, Chen D, Liu Q, Ma W and Xiong G et al 2018 Proc Natl Acad Sci USA 115 4033-8

33. Pascal A, Liu Z, Broess K, van Oort B, van Amerongen H, Wang C, Horton P, Robert B, Chang W and Ruban A 2005 Nature 436 134-7 